\title{
TEMPERATURE AND pH OF THE NUTRIENT SOLUTION ON WHEAT PRIMARY ROOT GROWTH
}

\author{
Carlos Eduardo de Oliveira Camargo*; Antonio Wilson Penteado Ferreira Filho; Marcus Vinicius \\ Salomon \\ IAC - Centro de Análise e Pesquisa Tecnológica do Agronegócio de Grãos e Fibras - C.P. 28 - 13001-970 - \\ Campinas, SP - Brasil. \\ *Corresponding author 〈ccamargo@iac.sp.gov.br>
}

\begin{abstract}
Primary root growth is very important for wheat (Triticum aestivum L.) crop in upland conditions in the State of São Paulo. Fourteen wheat genotypes (mutant lines and cultivars) were evaluated for primary root growth during 7 and 15 days of development in complete and aerated nutrient solutions, in the laboratory. In the first experiment, solutions with three $\mathrm{pH}$ values $(4.0,5.0$ and 6.0$)$ at constant temperature $\left(24 \pm 1^{\circ} \mathrm{C}\right)$, and in the second experiment, solutions with the same $\mathrm{pH}(4.0)$ but with three temperatures $\left(18^{\circ} \mathrm{C} \pm 1{ }^{\circ} \mathrm{C}\right.$, $24^{\circ} \mathrm{C} \pm 1^{\circ} \mathrm{C}$ and $30^{\circ} \mathrm{C} \pm 1^{\circ} \mathrm{C}$ ) were used. High genetic variability was observed among the evaluated genotypes in relation to primary root growth in the first stages of development in nutrient solutions independent of $\mathrm{pH}$, temperature and growth period. Genotypes 6 (BH-1146) and 13 (IAC-17), tolerant to $\mathrm{Al}^{3+}$ showed genetic potential for root growth in the first stages of development ( 7 and 15 days), regardless of nutrient solution temperature and pH. Genotypes 14 (IAC-24 M), 15 (IAC-24), 17 (MON"S" / ALD "S") × IAC-24 M, 18 (MON"S" / ALD "S") × IAC-24 $\mathrm{M}_{3}$ and 24 (KAUZ"S" / IAC-24 $\mathrm{M}_{3}$ ), tolerant to $\mathrm{Al}^{3+}$, showed reduced root growth under the same conditions.
\end{abstract}

Key words: Triticum aestivum L., upland crop, root growth

\section{TEMPERATURA E pH DA SOLUÇÃO NUTRITIVA NO CRESCIMENTO DAS RAÍZES PRIMÁRIAS DO TRIGO}

\begin{abstract}
RESUMO: O crescimento das raízes primárias é de grande importância para o estabelecimento da cultura do trigo (Triticum aestivum L.) em condição de sequeiro no Estado de São Paulo. Quatorze genótipos (linhagens mutantes e cultivares) de trigo foram comparados quanto ao crescimento das raízes primárias durante 7 e 15 dias de desenvolvimento em soluções nutritivas completas, com arejamento, em condição de laboratório. No primeiro experimento, empregaram-se soluções com três valores de $\mathrm{pH}(4,0 ; 5,0$ e 6,0$)$ mantendo-se constante a temperatura $\left(24 \pm 1^{\circ} \mathrm{C}\right)$ e no segundo, utilizaram-se soluções com mesmo pH $(4,0)$, porém com três temperaturas $\left(18^{\circ} \mathrm{C} \pm 1^{\circ} \mathrm{C}, 24^{\circ} \mathrm{C} \pm 1^{\circ} \mathrm{C}\right.$ e $\left.30^{\circ} \mathrm{C} \pm 1^{\circ} \mathrm{C}\right)$. Observou-se grande variabilidade genética entre os genótipos avaliados para crescimento das raízes primárias nos primeiros estádios de desenvolvimento independentemente do $\mathrm{pH}$, temperatura e período de crescimento nas soluções nutritivas. Os genótipos 6 (BH-1146) e 13 (IAC-17), tolerantes ao $\mathrm{Al}^{3+}$ exibiram potencial genético para maior crescimento radicular nos primeiros estádios de desenvolvimento ( 7 e 15 dias), independentemente da temperatura e do $\mathrm{pH}$ das soluções nutritivas. Os genótipos 14 (IAC-24 M), 15 (IAC-24), 17 (MON"S" / ALD “S”) × IAC-24 M, 18 (MON"S" / ALD “S”) ×IAC-24 M e 24 (KAUZ”S" / IAC-24 M 3 ), tolerantes ao $\mathrm{Al}^{3+}$, apresentaram reduzido crescimento radicular nas mesmas condições.

Palavras-chave: Triticum aestivum L., cultura de sequeiro, crescimento radicular
\end{abstract}

\section{INTRODUCTION}

In Brazil, wheat is cultivated in upland acidic soil conditions, in rotations with soybean [Glycine $\max (\mathrm{L}$.) Merr.] or (and) maize (Zea mays L.) crops, in the period of April to August. The development of plants with higher yielding potential, semi-dwarf, resistant to diseases, tolerant to aluminum toxicity and showing good nutritive and technological qualities, are the main goals of the brazilian wheat breeding programs for acidic soils. In addition, inbred-line breeding and selection for longer primary roots is important considering the short sowing pe- riod (April) when the occurrence of water stress associated or not with short periods of high air-temperature, namely "heat shocks" is frequent (Mundstock, 1983). Besides the $\mathrm{Al}^{3+}$-tolerance, plants must have long primary roots in the initial growth stages, to allow for good crop establishment. Such periods of drought stress may also occur from May to August, requiring that plants have longer adventitious roots able to reach deeper into the soil.

The mechanisms involved in drought resistance in wheat include early grain maturation, allowing that harvest happens before the period of water stress; vigorous 
and deep root system able to use the soil available moisture efficiently, stomata closure ability to reduce water loss, and a waxy leaf surface to avoid transpiration (Poehlman \& Sleper, 1995).

The early wheat cultivar BH-1146, highly $\mathrm{Al}^{3+}$ - tolerant in acidic soils, has also shown high tolerance to drought compared to other cultivars. Previous research using $\mathrm{Al}$-free nutrient solution has shown that the cultivar has the longest root system compared to other 26 wheat genotypes (Camargo et al., 1995). Similar results were reported by Camargo \& Oliveira (1981a), studying BH-1146 under non-limiting nutrient level, Alfree, $\mathrm{pH} 4.0$ solution who reported a higher potential for root growth in these plants, evidencing their specificity for this trait.

The use of gamma radiation in seeds of some wheat cultivars generated plants with specific agronomic characteristics, such as tolerance to $\mathrm{Al}$, usually present in acidic soils (Camargo et al., 1997; Tulmann Neto et al., 1995a; 1995b; 1996 and 2001). Most of the published research on this subject has been done in the presence of $\mathrm{Al}^{3+}$ and has shown that in the wheat early development stages, root growth is affected by temperature, $\mathrm{pH}$, salts and phosphorus concentrations of the nutrient solutions (Ali, 1973; Camargo \& Oliveira, 1981a; Camargo, 1983; 1984; Moore, 1974; Moore et al., 1976).

The objective of this research was to evaluate the root growth of several wheat genotypes (mutant inbred lines and cultivars) after 7 and 15 days of growth in nutrient solutions without $\mathrm{Al} 3+$, under different temperature and $\mathrm{pH}$ conditions.

\section{MATERIAL AND METHODS}

Two experiments were conducted in the laboratory. The first was set up with variable nutrient solution $\mathrm{pH}$ values and controlled temperature, and the second, with variable nutrient solution temperatures and controlled $\mathrm{pH}$, in order to evaluate the $\mathrm{pH}$ and temperature effects on the wheat seedling primary root growth. Fourteen genotypes were used in each experiment (Table 1), which were previously selected from 45 genotypes as to root growth in nutrient solutions (Camargo et al., 2002). Except for the cultivar Anahuac and the mutant line Anahuac $\mathrm{M}_{3}$, both susceptible to $\mathrm{Al}^{3+}$ toxicity (no growth of primary central roots after 48-hour treatment in nutrient solution containing $2 \mathrm{mg} \mathrm{L}^{-1}$ of $\mathrm{Al}^{3+}$ ), all the other genotypes evaluated had shown tolerance to $\mathrm{Al}^{3+}$ toxicity, i.e. root growth after a 48-hour treatment in nutrient solution containing $10 \mathrm{mg} \mathrm{L}^{-1}$ of $\mathrm{Al}^{3+}$, according to technique developed by Camargo \& Oliveira (1981a).

In experiment 1 , seeds of wheat genotypes (origi-

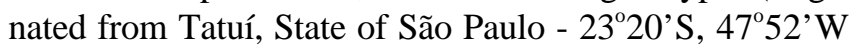
alt. $600 \mathrm{~m}$ - harvested in 1999 and stored in cold/dry chamber) were rinsed in $10 \%$ sodium hypochloride solution and put to germinate in Petri dishes in the refrigerator at $12^{\circ} \mathrm{C}$ during $72 \mathrm{~h}$. After this period, root emer-

Table 1 - Primary root length of wheat genotypes after 7-day-growth in complete nutrient solutions at $24 \pm 1^{\circ} \mathrm{C}$ temperature under three $\mathrm{pH}$ values.

\begin{tabular}{|c|c|c|c|}
\hline \multirow{3}{*}{ Genotype } & \multicolumn{3}{|c|}{ Primary root length ${ }^{(1)}$} \\
\hline & \multicolumn{3}{|c|}{$\mathrm{pH}$ values } \\
\hline & 4.0 & 5.0 & 6.0 \\
\hline & - & mm - & $-\ldots-\cdots$ \\
\hline 1- BH-1146 $\mathrm{M}_{1}$ & $139 \mathrm{~d}-\mathrm{g}$ & $140 \mathrm{~cd}$ & $151 \mathrm{ab}$ \\
\hline 2- BH-1146 $\mathrm{M}_{2}$ & $144 \mathrm{c}-\mathrm{f}$ & $138 \mathrm{~d}$ & $126 \mathrm{~d}-\mathrm{f}$ \\
\hline $6-$ ВH-1146 & $162 \mathrm{ab}$ & $161 \mathrm{a}$ & $153 \mathrm{a}$ \\
\hline 8- Anahuac $\mathrm{M}_{1}$ & $153 \mathrm{a}-\mathrm{c}$ & $143 b-d$ & $139 \mathrm{~b}-\mathrm{d}$ \\
\hline 10- Anahuac $\mathrm{M}_{3}$ & $150 \mathrm{~b}-\mathrm{e}$ & $144 \mathrm{~b}-\mathrm{d}$ & $147 \mathrm{ab}$ \\
\hline 11- Anahuac & $137 \mathrm{e}-\mathrm{g}$ & $135 \mathrm{de}$ & $140 \mathrm{a}-\mathrm{c}$ \\
\hline 12- IAC-17 M & $152 \mathrm{a}-\mathrm{d}$ & $149 \mathrm{bc}$ & $146 \mathrm{ab}$ \\
\hline 13- IAC-17 & $165 \mathrm{a}$ & $151 \mathrm{~b}$ & $148 \mathrm{ab}$ \\
\hline 14- IAC-24 M & $131 \mathrm{fg}$ & $121 \mathrm{f}$ & $114 \mathrm{fg}$ \\
\hline $15-\mathrm{IAC}-24$ & $137 \mathrm{e}-\mathrm{g}$ & $122 \mathrm{f}$ & $126 \mathrm{~d}-\mathrm{f}$ \\
\hline 17- (MON"S" / ALD "S") x IAC-24 $\mathrm{M}_{2}$ & $138 \mathrm{e}-\mathrm{g}$ & 135 de & 123 ef \\
\hline 18- (MON"S" / ALD "S") x IAC-24 $\mathrm{M}_{3}$ & $143 \mathrm{c}-\mathrm{f}$ & $128 \mathrm{ef}$ & $113 \mathrm{fg}$ \\
\hline 22- KAUZ"S" / IAC-24 $\mathrm{M}_{1}$ & $150 \mathrm{~b}-\mathrm{e}$ & $143 \mathrm{~b}-\mathrm{d}$ & $132 \mathrm{c}-\mathrm{e}$ \\
\hline 24- KAUZ"S" / IAC-24 M & $129 \mathrm{~g}$ & $110 \mathrm{~g}$ & $106 \mathrm{~g}$ \\
\hline Means & $145 \mathrm{~A}$ & $137 \mathrm{~B}$ & $133 \mathrm{~B}$ \\
\hline
\end{tabular}

${ }^{(1)}$ Means followed by the same letters are not different by Duncan's test (0.05).

Sci. Agric. (Piracicaba, Braz.), v.61, n.3, p.313-318, May/June 2004 
gence was starting and 25 germinated seeds of each genotype were put on top of a nylon netting, using nippers, adapted over 8.3 L-plastic recipients, containing complete full strength nutrient solutions, with three $\mathrm{pH}$ treatments: 4.0, 5.0 and 6.0. The treatment solutions were arranged in a randomized complete block design with two replications. The nylon netting with the seeds on top was kept in contact with a complete nutrient solution, which consisted of the following nutrient concentrations: $\mathrm{Ca}\left(\mathrm{NO}_{3}\right)_{2}$ $4 \mathrm{mmol} \mathrm{L}^{-1}, \mathrm{MgSO}_{4} 2 \mathrm{mmol} \mathrm{L}^{-1}, \mathrm{KNO}_{3} 4 \mathrm{mmol} \mathrm{L}^{-1}$, $\left(\mathrm{NH}_{4}\right)_{2} \mathrm{SO}_{4} 0.435 \mathrm{mmol} \mathrm{L}^{-1}, \mathrm{KH}_{2} \mathrm{PO}_{4} 0.5 \mathrm{mmol} \mathrm{L}^{-1}, \mathrm{MnSO}_{4}$ $2 \mu \mathrm{mol} \mathrm{L}^{-1}, \mathrm{CuSO}_{4} 0.3 \mu \mathrm{mol} \mathrm{L}^{-1}, \mathrm{ZnSO}_{4} 0.8 \mu \mathrm{mol} \mathrm{L}^{-1}, \mathrm{NaCl}$ $30 \mu \mathrm{mol} \mathrm{L}^{-1}$, Fe-CYDTA $10 \mu \mathrm{mol} \mathrm{L}{ }^{-1}, \mathrm{Na}_{2} \mathrm{MoO}_{4}$ $0.10 \mu \mathrm{mol} \mathrm{L}^{-1}$ and $\mathrm{H}_{3} \mathrm{BO}_{3} 10 \mu \mathrm{mol} \mathrm{L}^{-1}$.

The nutrient solution $\mathrm{pH}$ treatments were adjusted using a $0.5 \mathrm{~mol} \mathrm{~L}^{-1} \mathrm{H}_{2} \mathrm{SO}_{4}$ or $1 \mathrm{~mol} \mathrm{~L}^{-1} \mathrm{NaOH}$ solution. The nutrient solutions in the recipients were continuously aerated and maintained in water-bath at $24 \pm 1{ }^{\circ} \mathrm{C}$, in the laboratory. After that, ten 7-day-old seedlings of each genotype were removed from each recipient and evaluated for central primary root length. The remaining seedlings were kept eight more days under the same conditions. After that ten other seedlings ( 15 days old) were sampled for root length measurements. During Experiment 1 , the $\mathrm{pH}$ treatments were adjusted daily to 4.0, 5.0 or 6.0 , in their respective recipients, using $0.5 \mathrm{~mol} \mathrm{~L}^{-1}$ $\mathrm{H}_{2} \mathrm{SO}_{4}$ or $1 \mathrm{~mol} \mathrm{~L}^{-1} \mathrm{NaOH}$ solutions.

The average primary root length of each genotype was calculated for the 7-day-old and 15-day-old seedlings, for each $\mathrm{pH}$ treatment. The data were submitted to analysis of variance (F test, 0.05 ), for a randomized complete block design with two replications, for the genotype effect, nutrient solution $\mathrm{pH}$ effect and the interaction genotype $\mathrm{x} \mathrm{pH}$ on the root growth. Mean comparisons were done using Duncan's test (0.05).

In Experiment 2, the same procedures and materials were used regarding seed germination, experimental design, recipient size and seed support, nutrient solution composition and aeration, and the same 14 genotypes. The nutrient solution $\mathrm{pH}$ was adjusted to 4.0. Treatments consisted of three nutrient solution temperatures: $18^{\circ} \mathrm{C} \pm 1{ }^{\circ} \mathrm{C}$, $24^{\circ} \mathrm{C} \pm 1^{\circ} \mathrm{C}$ and $30^{\circ} \mathrm{C} \pm 1^{\circ} \mathrm{C}$. The $8.3 \mathrm{~L}$ - plastic recipients with nutrient solutions were kept in water-bath with temperature control. Ten 7-day-old and 15-day-old seedlings were sampled for the primary root length measurements. During this period, nutrient solution $\mathrm{pH}$ was monitored and adjusted daily to as close as possible to 4.0 , with $0.5 \mathrm{~mol}$ $\mathrm{L}^{-1} \mathrm{H}_{2} \mathrm{SO}_{4}$ and/or $1 \mathrm{~mol} \mathrm{~L}^{-1} \mathrm{NaOH}$ solutions.

The primary root length data were submitted to analysis of variance (F test, 0.05 ) for randomized complete block with two replications, for the genotype effect, temperature effect and interaction effect (genotypes $\times$ temperatures). Mean comparisons among genotypes within each temperature treatment and among different temperatures were done by the Duncan's test (0.05).

\section{RESULTS AND DISCUSSION}

Experiment 1 - The ANOVA for root growth data obtained during 7 and 15 days in complete nutrient solution, with $\mathrm{pH}$ values of 4.0; 5.0 and 6.0 showed effects of genotype and $\mathrm{pH}$ but no interactions between the two.

Root growth measured on the $7^{\text {th }}$ day $(145 \mathrm{~mm}-$ Table 1) and on the $15^{\text {th }}$ day (222 $\mathrm{mm}$ - Table 2) in $\mathrm{pH}$ 4.0 solutions were higher when compared to the root growth of the same genotypes and age at pH 6.0 (133 and $198 \mathrm{~mm}$, respectively). These results are consistent with those of Camargo (1984) who found a reduction trend in wheat root growth as $\mathrm{pH}$ increased from 4.0 to 6.0 when cultivated in complete nutrient solution.

Lower root growth at higher $\mathrm{pH}$, in the absence of $\mathrm{Al}^{3+}$ may be due to lower phosphorus uptake and lower availability of iron and other micronutrients (Salisbury \& Ross, 1969). This conflicts with the situation where a constant amount of aluminum is supplied in the nutrient solution and $\mathrm{pH}$ is changed from 4.0 to 6.0 , and where reasonable root growth of wheat seedlings takes place in $\mathrm{pH}$ 6.0 (Camargo, 1984). The hydrolysis theory may elucidate this, since a 10-fold trivalent aluminum $\left(\mathrm{Al}^{3+}\right)$ compared to bivalent form $\left(\mathrm{AlOH}^{2+}\right)$ occurs under $\mathrm{pH} 4.0 ; 3.1$ fold at $\mathrm{pH} 4.5$; while at $\mathrm{pH} 5.0$ the trivalent and bivalent ionic species are practically equivalent (Foy \& Fleming, 1978).

Experiment 2 - The ANOVA for wheat root growth data over 7 and 15 days in complete nutrient solution under three temperatures showed effects of genotype and solution temperature but no interactions between the two.

The average 14 genotypes root growth after 7 days (117 $\mathrm{mm}$ - Table 3$)$ and 15 days (208 $\mathrm{mm}$ - Table 4) in nutrient solution at $18^{\circ} \mathrm{C}$ was lower $(P<0.05)$ than the growth for the same genotypes and growth periods at $30^{\circ} \mathrm{C}$ (143 and $260 \mathrm{~mm}$, respectively). This is not consistent with the data of Camargo (1983) who found a trend of wheat root growth reduction with increasing solution temperature from 22 to $34^{\circ} \mathrm{C}$, in solution with varying aluminum concentrations. The same was found by Benitez (1977) for the rye cultivar 1443 which showed root growth in nutrient solution with $35 \mathrm{mg} \mathrm{L}^{-1}$ of $\mathrm{Al}^{3+}$ at $25^{\circ} \mathrm{C}$ but not with 20 $\mathrm{mg} \mathrm{L}^{-1}$ of $\mathrm{Al}^{3+}$ at $30^{\circ} \mathrm{C}$. According to the author the higher temperature increased the proportion of aluminum uptake induced by metabolic processes.

With the exception of Anahuac and Anahuac $\mathrm{M}_{3}$ all genotypes were tolerant to $\mathrm{Al}^{3+}$ toxicity, i.e., showed root growth in standard nutrient solution after 48 hours in a solution with $10 \mathrm{mg} \mathrm{L}^{-1}$ of $\mathrm{Al}^{3+}$ (Tulmann Neto et al., 2001). The non-tolerant genotypes do not show root growth in similar conditions due to the occurrence of an irreversible damage in the primary root apical meristem. The classification proposed by Moore et al. (1976) and modified by Camargo \& Oliveira (1981a), considers as 
Table 2 - Primary root length of wheat genotypes after 15-day-growth in complete nutrient solutions at $24 \pm 1^{\circ} \mathrm{C}$ temperature under three $\mathrm{pH}$ values

\begin{tabular}{|c|c|c|c|}
\hline \multirow{3}{*}{ Genotype } & \multicolumn{3}{|c|}{ Primary root growth ${ }^{(1)}$} \\
\hline & \multicolumn{3}{|c|}{$\mathrm{pH}$ values } \\
\hline & 4.0 & 5.0 & 6.0 \\
\hline \multicolumn{4}{|c|}{ - } \\
\hline 1- BH-1146 $\mathrm{M}_{1}$ & $215 \mathrm{~d}-\mathrm{g}$ & 229 b-e & 216 a-c \\
\hline 2- BH-1146 $\mathrm{M}_{2}$ & $213 \mathrm{~d}-\mathrm{g}$ & $223 \mathrm{~b}-\mathrm{e}$ & $204 \mathrm{bc}$ \\
\hline $6-\mathrm{BH}-1146$ & $267 \mathrm{ab}$ & 277 a & $240 \mathrm{a}$ \\
\hline 8- Anahuac $\mathrm{M}_{1}$ & $245 \mathrm{a}-\mathrm{d}$ & 236 a-d & $209 \mathrm{bc}$ \\
\hline 10- Anahuac $\mathrm{M}_{3}$ & $232 b-e$ & 238 a-c & $224 \mathrm{ab}$ \\
\hline 11- Anahuac & $197 \mathrm{e}-\mathrm{g}$ & $222 b-e$ & $217 \mathrm{a}-\mathrm{c}$ \\
\hline 12- IAC-17 M & 256 a-c & $260 \mathrm{ab}$ & $226 \mathrm{ab}$ \\
\hline 13- IAC-17 & $271 \mathrm{a}$ & $263 \mathrm{ab}$ & $221 \mathrm{a}-\mathrm{c}$ \\
\hline 14- IAC-24 M & $209 \mathrm{~d}-\mathrm{g}$ & 187 e & 170 de \\
\hline $15-$ IAC- 24 & $197 \mathrm{e}-\mathrm{g}$ & $192 \mathrm{de}$ & $167 \mathrm{de}$ \\
\hline 17- (MON"S" / ALD "S") x IAC-24 $\mathrm{M}_{2}$ & $191 \mathrm{~g}$ & $200 \mathrm{c}-\mathrm{e}$ & $170 \mathrm{de}$ \\
\hline 18- (MON"S" / ALD "S") x IAC-24 $\mathrm{M}_{3}$ & $194 \mathrm{fg}$ & $187 \mathrm{e}$ & 155 e \\
\hline 22- KAUZ"S" / IAC-24 $\mathrm{M}_{1}$ & $229 \mathrm{c}-\mathrm{f}$ & $228 \mathrm{~b}-\mathrm{e}$ & $194 \mathrm{~cd}$ \\
\hline 24- KAUZ"S" / IAC-24 M & $187 \mathrm{~g}$ & $186 \mathrm{e}$ & 165 de \\
\hline Means & $222 \mathrm{~A}$ & $223 \mathrm{~A}$ & $198 \mathrm{~B}$ \\
\hline
\end{tabular}

${ }^{\overline{(1)}}$ Means followed by the same letters are not different by Duncan's test $(0.05)$.

Table 3 - Primary root length of wheat genotypes after 7-day-growth in complete nutrient solutions under $\mathrm{pH} 4.0$ and three temperatures.

\begin{tabular}{|c|c|c|c|}
\hline \multirow{3}{*}{ Genotype } & \multicolumn{3}{|c|}{ Primary root length ${ }^{(1)}$} \\
\hline & \multicolumn{3}{|c|}{ Temperature } \\
\hline & $18^{\circ} \mathrm{C} \pm 1{ }^{\circ} \mathrm{C}$ & $24^{\circ} \mathrm{C} \pm 1^{\circ} \mathrm{C}$ & $30^{\circ} \mathrm{C} \pm 1{ }^{\circ} \mathrm{C}$ \\
\hline & -1-n-n & $----m m---$ & - n \\
\hline $1-$ BH-1146 M & $112 \mathrm{e}-\mathrm{g}$ & $130 \mathrm{~d}-\mathrm{f}$ & $138 \mathrm{~b}-\mathrm{d}$ \\
\hline 2- $\mathrm{BH}-1146 \mathrm{M}_{2}$ & $119 \mathrm{c}-\mathrm{e}$ & $140 \mathrm{~b}-\mathrm{d}$ & $128 \mathrm{~cd}$ \\
\hline 6- ВН-1146 & $132 \mathrm{a}$ & 159 a & $175 \mathrm{a}$ \\
\hline 8- Anahuac $\mathrm{M}_{1}$ & $130 \mathrm{ab}$ & $152 \mathrm{ab}$ & $164 \mathrm{a}$ \\
\hline 10- Anahuac $\mathrm{M}_{3}$ & $127 \mathrm{a}-\mathrm{c}$ & $152 \mathrm{ab}$ & $162 \mathrm{a}$ \\
\hline 11- Anahuac & $110 \mathrm{fg}$ & 127 ef & $140 \mathrm{bc}$ \\
\hline 12- IAC-17 M & $122 b-d$ & $136 \mathrm{c}-\mathrm{e}$ & $144 \mathrm{~b}$ \\
\hline 13- IAC-17 & $131 \mathrm{ab}$ & $146 \mathrm{bc}$ & $163 \mathrm{a}$ \\
\hline 14- IAC-24 M & $107 \mathrm{~g}$ & 127 ef & $128 \mathrm{~b}-\mathrm{d}$ \\
\hline $15-\mathrm{IAC}-24$ & $113 \mathrm{e}-\mathrm{g}$ & $123 \mathrm{f}$ & $128 \mathrm{~b}-\mathrm{d}$ \\
\hline 17- (MON"S" / ALD "S") x IAC-24 $\mathrm{M}_{2}$ & $117 \mathrm{~d}-\mathrm{f}$ & 124 ef & $126 \mathrm{~cd}$ \\
\hline 18- (MON"S" / ALD "S") x IAC-24 $\mathrm{M}_{3}$ & $110 \mathrm{fg}$ & $131 \mathrm{~d}-\mathrm{e}$ & $145 \mathrm{~b}$ \\
\hline 22- KAUZ"S" / IAC-24 M & $108 \mathrm{~g}$ & $136 \mathrm{c}-\mathrm{e}$ & $143 \mathrm{~b}$ \\
\hline 24- KAUZ"S" / IAC-24 $\mathrm{M}_{3}$ & $96 \mathrm{~h}$ & $122 \mathrm{f}$ & $124 \mathrm{~d}$ \\
\hline Means & $117 \mathrm{~A}$ & $136 \mathrm{~B}$ & $143 \mathrm{C}$ \\
\hline
\end{tabular}

${ }^{(1)}$ Means followed by the same letters are not different by Duncan's test $(0.05)$.

tolerant a genotype that shows some root growth and nontolerant when no growth is detected. In practice, a tolerant genotype may show higher or lower root growth in relation to another tolerant genotype in the same conditions (Camargo \& Oliveira, 1981a).
The difference between a tolerant and a non-tolerant genotype to a given toxic $\mathrm{Al}^{3+}$ concentration is due to a pair of dominant alleles (Camargo et al., 2000b). Data from this research suggest that the pair of alleles linked to $\mathrm{Al}^{3+}$ toxicity tolerance would not be the same genes 
Table 4 - Primary root length of wheat genotypes after 15-day-growth in complete nutrient solutions under $\mathrm{pH} 4.0$ and three temperatures.

\begin{tabular}{|c|c|c|c|}
\hline \multirow{3}{*}{ Genotype } & \multicolumn{3}{|c|}{ Primary root length ${ }^{(1)}$} \\
\hline & \multicolumn{3}{|c|}{ Temperature } \\
\hline & $18^{\circ} \mathrm{C} \pm 1^{\circ} \mathrm{C}$ & $24^{\circ} \mathrm{C} \pm 1^{\circ} \mathrm{C}$ & $30^{\circ} \mathrm{C} \pm 1{ }^{\circ} \mathrm{C}$ \\
\hline & 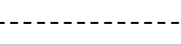 & $----m m---$ & $-\cdots-1$ \\
\hline $1-$ BH-1146 M & 205 de & $226 \mathrm{c}-\mathrm{e}$ & $270 \mathrm{~b}-\mathrm{e}$ \\
\hline 2- BH-1146 M & $211 \mathrm{~cd}$ & $230 \mathrm{~cd}$ & $247 \mathrm{e}-\mathrm{g}$ \\
\hline 6- BH-1146 & $253 \mathrm{a}$ & 284 a & 349 a \\
\hline 8- Anahuac M1 & $226 \mathrm{bc}$ & $248 \mathrm{~b}-\mathrm{d}$ & $295 \mathrm{bc}$ \\
\hline 10- Anahuac $\mathrm{M}_{3}$ & $229 \mathrm{bc}$ & $240 \mathrm{~b}-\mathrm{d}$ & $288 \mathrm{~b}-\mathrm{d}$ \\
\hline 11- Anahuac & $197 \mathrm{~d}-\mathrm{f}$ & $214 \mathrm{~d}-\mathrm{f}$ & $259 \mathrm{c}-\mathrm{f}$ \\
\hline 12- IAC-17 M & $231 \mathrm{a}-\mathrm{c}$ & $254 a-c$ & $285 \mathrm{~b}-\mathrm{d}$ \\
\hline 13- IAC-17 & $235 \mathrm{ab}$ & $270 \mathrm{ab}$ & $306 \mathrm{~b}$ \\
\hline 14- IAC-24 M & $176 \mathrm{f}$ & 193 ef & $224 \mathrm{fg}$ \\
\hline $15-\mathrm{IAC}-24$ & 185 ef & 194 ef & $211 \mathrm{~g}$ \\
\hline 17- (MON"S" / ALD "S") x IAC-24 $\mathrm{M}_{2}$ & $182 \mathrm{f}$ & 192 ef & $222 \mathrm{fg}$ \\
\hline 18- (MON"S" / ALD "S") x IAC-24 $\mathrm{M}_{3}$ & $189 \mathrm{~d}-\mathrm{f}$ & $188 \mathrm{f}$ & $218 \mathrm{~g}$ \\
\hline 22- KAUZ"S" / IAC-24 M & $211 \mathrm{~cd}$ & $225 \mathrm{c}-\mathrm{e}$ & $256 \mathrm{~d}-\mathrm{f}$ \\
\hline 24- KAUZ"S" / IAC-24 $\mathrm{M}_{3}$ & $181 \mathrm{f}$ & 194 ef & $212 \mathrm{~g}$ \\
\hline Means & $208 \mathrm{~A}$ & $225 \mathrm{~B}$ & $260 \mathrm{C}$ \\
\hline
\end{tabular}

(1) Means followed by the same letters are not different by Duncan's test $(0.05)$.

involved in the control of root growth in the absence of aluminum stress. Furthermore, it would not be correct to state that a genotype is more Al-tolerant than another based upon a higher root growth in solutions without aluminum, after a developing period in solutions with a given aluminum content, as proposed by Camargo et al., 1995 and Camargo, 1993.

Despite the decrease in root growth as nutrient solution $\mathrm{pH}$ increased from 4.0 to 6.0 and the opposite reaction as temperature raised from 18 to $30^{\circ} \mathrm{C}$, considering the average values, all tested genotypes showed similar response to the solution $\mathrm{pH}$ and temperature treatments. This was confirmed by the absence of interactions between genotype and $\mathrm{pH}$ and between genotype and temperature in the nutrient solutions. At lower temperatures root growth usually surpasses that of above-ground parts, but as temperature raises, both plant parts have increased growth, although, shoots grow at a faster rate than roots (Evans, 1975).

It has been suggested that root growth is genetically controlled and is little affected by environment $(\mathrm{pH}$ and temperature) in the same way as tall genotypes differ from dwarf ones (Camargo et al., 2000a). High restrict sense heritability values for plant height were found by several authors (Johnson et al., 1966; Camargo et al., 1980, 2000a), thus, indicating that this trait is controlled by a few genes (Camargo \& Oliveira, 1981b), with environment not playing an important role upon their expression. Consequently, successful selection in segregating populations can be performed in the $\mathrm{F}_{2}$ generation.
To demonstrate that root growth is genetically controlled, crosses between high and reduced root growth genotypes should be done and seedlings from $\mathrm{F}_{2}$ and $\mathrm{F}_{3}$ generations selected according its growth ability in nutrient solution. As a result, in the segregating generations distribution frequencies, heritabilities for this trait as well as the number of involved genes for the root growth could be established. In the future, selected lines with high root growth could be incorporated in the wheat breeding program to develop genotypes well adapted to the State of São Paulo short sowing period (April), when the occurrence of moisture stresses is common, thus improving the chances of successful crops.

\section{ACKNOWLEDGEMENTS}

To 'Fundação de Amparo à Pesquisa do Estado de São Paulo' (FAPESP), to the International Atomic Energy Agency (IAEA) Vienna, Austria and to 'Conselho Nacional de Desenvolvimento Científico e Tecnológico' $(\mathrm{CNPq})$ for the financial support and scholarships.

\section{REFERENCES}

ALI, S.M.E. Influence of cations on aluminum toxicity in wheat (Triticum aestivum Vill., Host). Corvallis: Oregon State University, 1973. 102p. (Thesis - Doctorate).

BENITEZ, A.L. Influence of aluminum toxicity in intergeneric crosses of wheat and rye. Corvallis: Oregon State University, 1977. 107p. (Thesis - Ph.D).

CAMARGO, C.E. de O. Efeito da temperatura da solução nutritiva na tolerância ao alumínio de cultivares de trigo. Bragantia, v.42, p.51-63, 1983. 
CAMARGO, C.E. de O. O pH das soluções nutritivas no comportamento de cultivares de trigo à toxicidade de alumínio. Bragantia, v.43, p.327335, 1984.

CAMARGO, C.E. de O. Trigo. In: FURLANI, A.M.C.; VIEGAS, G.P. (Ed.) O melhoramento de plantas no Instituto Agronômico. Campinas: Instituto Agronômico, 1993. cap.12, p.433-488.

CAMARGO, C.E. de O.; OLIVEIRA, O.F. Tolerância de cultivares de trigo a diferentes níveis de alumínio em solução nutritiva e no solo. Bragantia, v.40, p.21-31, 1981a.

CAMARGO, C.E. de O.; OLIVEIRA, O.F. Melhoramento do trigo. II. Estudo genético de fontes de nanismo para a cultura do trigo. Bragantia, v.40, p.77-91, 1981b.

CAMARGO, C.E. de O.; FELICIO, J.C.; TULMANN NETO, A.; FERREIRA FILHO, A.W.P.; PETTINELLI JR., A.; CASTRO, J.L. de. Melhoramento do trigo: XXVIII. Novos genótipos obtidos por seleções em população segregante interespecífica submetida à irradiação gama. Bragantia, v.54, p.51-65, 1995.

CAMARGO, C.E. de O.; FERREIRA FILHO, A.W.P.; FELICIO, J.C. Estimativas de herdabilidade e correlações quanto à produção de grãos e outras características agronômicas em populações de trigo. Pesquisa Agropecuária Brasileira, v.35, p.369-379, 2000a.

CAMARGO, C.E. de O.; KRONTAD, W.E.; METZGER, R.J. Parentprogeny regression estimates and associations of height levels with aluminum toxicity and grain yield in wheat. Crop Science, v.20, p.255358, 1980.

CAMARGO, C.E. de O.; TULMANN NETO, A.; FERREIRA FILHO, A.W.P.; FELICIO, J.C.; CASTRO, J.L. de; PETTINELLI JR., A. Novos genótipos de trigo (Triticum aestivum L.) obtidos por irradiação gama. Scientia Agricola, v.54, p.195-202, 1997.

CAMARGO, C.E. de O.; TULMANN NETO, A.; FERREIRA FILHO, A.W.P.; FELICIO, J.C. Genetic control of aluminum tolerance in mutant lines of the wheat cultivar Anahuac. Euphytica, v.114, p.47-53, 2000 b.

CAMARGO, C.E. de O.; FERREIRA FILHO, A.W.P.; RAMOS, L.C. da S.; FELICIO, J.C.; TULMANN NETO, A. Primary root growth: genetics and differential among wheat mutant lines in nutrient solutions. In: RESEARCH CO-ORDINATION MEETING OF FAO/IAEA COORDINATED RESEARCH PROJECT ON MUTATIONAL ANALYSIS OF ROOT CHARACTERS IN ANNUAL FOOD PLANTS RELATED TO PLANT PERFORMANCE, 1., Viena, 2000. Report. Viena: IAEA, 2002. p.43-46.

EVANS, L.T. Crop physiology some case histories. Cambridge: Cambridge University Press, 1975. 374p.
FOY, C.D.; FLEMING, A.L. The physiology of plant tolerance to excess available aluminum and manganese in acid soils. In: CROP TOLERANCE TO SUBOPTIMAL LAND CONDITIONS, Houston, 1978. Proccedings. Madison: ASA, 1978. p.301-328.

JOHNSON, V.A.; BIEVER, K.J.; HAUNOLD, A.; SCHMIDT. J.W. Inheritance of plant height, yield of grain, and other plant and seed characteristics in a cross of hard red winter wheat, Triticum aestivum $\mathrm{L}$. Crop Science, v.6, p.336-338, 1966.

MOORE, D.P. Physiological effects of $\mathrm{pH}$ on plant roots. In: CARSON, E.W. (Ed.) The plant root and its environment. Charlottesville: University Press of Virginia, 1974. p.135-151.

MOORE, D.P.; KRONSTAD, W.E.; METZGER, R.J. Screening wheat for aluminum tolerance. In: WORKSHOP ON PLANT ADAPTATION TO MINERAL STRESS IN PROBLEM SOILS, Beltsville, 1976. Proccedings. Ithaca: Cornell University, 1976. p.287-295.

MUNSTOCK, C.M. Cultivo dos cereais de estação fria: trigo, cevada, aveia, centeio, alpiste e triticale. 1.ed. Porto Alegre: Gráfica e Editora NBS Ltda, 1983. 265p.

POEHLMAN, J.N.; SLEPER, D.A. Breeding field crops. 4.ed. Ames: Iowa State University Press, 1995. 494p.

SALISBURY, F.B.; ROSS, C. Plant physiology. Belmont: Wadsworth Publishing Company, 1969. 747p.

TULMANN NETO, A.; CAMARGO, C.E. de O.; ALVES, M.C.; CASTRO, J.L. de; GALLO, P.B. Indução de mutação visando a redução de altura de planta e resistência às doenças no cultivar de trigo (Triticum aestivum L.) IAC-17. Scientia Agricola, v.52, p.287-293, 1995a.

TULMANN NETO, A.; CAMARGO, C.E. de O.; ALVES, M.C.; SANTOS, R.R. dos; FREITAS, J.G. de. Indução de mutação visando a obtenção de resistência às doenças na cultivar de trigo IAC-24. Pesquisa Agropecuária Brasileira, v.30, p.497-504, 1995b.

TULMANN NETO, A.; CAMARGO, C.E. de O.; PETTINELLI JR., A.; FERREIRA FILHO, A.W.P. Plant height reduction and disease resistance in wheat (Triticum aestivum L.) cultivar IAC-18 by gamma irradiationinduced mutations. Revista Brasileira de Genética, v.19, p.275-281, 1996.

TUlMANN NETO, A.; CAMARGO, C.E. de O.; CASTRO, J.L. de; FERREIRA FILHO, A.W.P. New Wheat (Triticum aestivum L.) genotypes tolerant to aluminum toxicity obtained by mutation breeding. Pesquisa Agropecuária Brasileira, v.36, p.61-70, 2001.

Received May 29, 2003

Accepted March 26, 2004 